\title{
A transitional man: Xavier Mina between Spain and America, 1789-1817
}

\author{
Karen Racine \\ Professor, University of Guelph, Canada \\ kracine@uoguelph.ca
}

Resumo: Francisco Xavier Mina foi a
personificação física da natureza
essencialmente transitória da Era das
Revoluções. Integrou uma nova geração de
líderes que nasceram quando os antigos
regimes estavam morrendo e que não tinham
absolutamente nenhum apego sentimental a
monarcas, tradições ou privilégios especiais.
Como líder de guerrilha na Espanha e no
México, ele e seus homens derrubaram
instituições ocultas e abriram o caminho para
que outros os seguissem e realizassem o
trabalho de construção de novas sociedades.
Como pensador político, as ideias de Mina
eram uma espécie de liberalismo não
escolarizado, mas entusiasmado, baseado nas
verdades simples e evidente de que todas as
pessoas eram iguais perante Deus e a lei e que
todos mereciam uma vida digna e decente.

Palavras-chave: Francisco Xavier Mina; Guerra Peninsular; Independência do México.

\begin{abstract}
Francisco Xavier Mina was the physical embodiment of the essentially transitional nature of the Age of Revolutions. He was part of a new generation of leaders who had been born as the ancién régimes were dying and who had absolutely no sentimental attachment to monarchs, traditions, or special privileges. As a guerrilla leader in both Spain and Mexico, he and his men toppled hidebound institutions and cleared the way for others to come after them and do the work of building new societies. As a political thinker, Mina's ideas were a sort of unschooled but enthusiastic liberalism based on the simple and self-evident truths that all people were equal before God and the law, and that everyone deserved a decent, dignified life.
\end{abstract}

Keywords: Francisco Xavier Mina, Peninsular War, Mexican independence. 
Francisco Xavier Mina was a man who lived fast and died young. He spent his short life on the battlegrounds of the many transitions that were occurring throughout the Atlantic World during the age of Revolutions. Mina was born in Navarra, a northern province in Spain that was both a historically distinct Kingdom with significant cultural and political autonomy, and a key region in the defence of the realm against the Napoleonic invaders. He mobilized a successful guerrilla resistance against the occupying forces but spent most of the War of Independence in a French jail where he not only learned the language but eventually came to appreciate the egalitarian thrust of the Revolution's early years. Mina identified fervently as a Spaniard and yet he led an expedition to Mexico in 1817 to strike a blow against the tyrant King Ferdinand VII by depriving him of his most valuable overseas territory. Francisco Xavier Mina was the physical embodiment of the essentially transitional nature of the Age of Revolutions. He was part of a new generation of leaders who had been born as the ancién régimes were dying and who grew up with absolutely no sentimental attachment to monarchs, traditions, or the extension of special privileges. As a guerrilla leader, Mina and his cohort toppled hidebound institutions and cleared the way for others to come after them and do the work of building new societies. As a political thinker, Mina's ideas were a sort of unschooled but enthusiastic liberalism based on the simple and self-evident truths that all people were equal before God and the law, and that all human beings deserved a decent, dignified life. Mina developed these ideas by operating throughout the rural areas of Spanish Navarre and the Mexican Bajío - places where politicians and the press did not necessarily penetrate - and, in so doing, opened a transitional space where people of the land began to think of themselves as citizens with political and economic rights. Francisco Xavier Mina was a transitional man in an Age of Transitions. That he died by firing squad in a foreign land might also have been warning that the transition was bloody and would come at a high cost.

\section{Navarra and the Formative Years}

The baby called Martín Xavier Mina y Larrea arrived in the world in July 1789, 
the same month that the French Revolution began. (ORTUÑO MARTÍNEZ, 2008: 20) ${ }^{1}$ He was born outside Pamplona in Navarra, one of the seven ethnically Basque provinces that straddle the border between Spain and France. Over time, Navarra had cultivated a more fluid interchange with the Spanish imperial state than had its neighboring provinces of Vizcaya, Gipuzkoa and Álava. In medieval times, it had been "a true kingdom in its own right," with a capital city, a Catholic bishopric, consistent political control over a defined territory, and an established dynastic elite. (BARD, 1982: XXII, 28) Over time, Navarran elites also developed a strong "foral tradition" [from the Spanish fuero, meaning enshrined rights and privileges] so that when the Kingdom was incorporated into the Crown of Castilla in 1513, its representatives negotiated a status that allowed Navarra to function as a region central to Spanish defence and commerce while also preserving important components of its legislative, fiscal, and cultural autonomy. (MINA APAT, 1981: 27-28) ${ }^{2}$ This sort of pactismo [rule by political compact] meant that Navarrans experienced "an economic, cultural and artistic renaissance" under Spanish Habsburg rule which included the population's rapid increase, and a steady improvement in the general standard of living that came from trade with the American colonies. (BURGO, 1992: Vol. 1, 581-582) On the other hand, Navarrans regularly resisted the Spanish Crown's attempts to impose laws and taxes on them from the center. Provincial uprisings were predictable only in their frequency which caused the Spanish monarchy to have to expend enormous sums not just to shore up the border with France, but also to placate - or, on many occasions, subjugate - the same people they expected to be their front-line defenders.

By the late eighteenth century, the Bourbon imperial state's aggressive reform agenda meant that a never-ending series of decrees, demands, taxes, and levies emanated from Madrid and began to provoke a backlash in Navarra. Following their French relatives' example, the Spanish Bourbons undertook a detailed census and then demanded that each town and region send $20 \%$ of its adult male population for military service. This mandatory order fell most heavily on the rural folk and the urban working class and proved to be wildly unpopular. (MINA APAT, 1981: 38-39) By 1778, the central state's bureaucrats regularly violated the centuries-old arrangement with the Kingdom of Navarra that had been based on the fueros and regional autonomy.

\footnotetext{
${ }^{1}$ Various authors have identified Mina's date of birth across a six-month spectrum from July 1 to December 3.

${ }^{2}$ Mina Apat argues that Navarran autonomy is a cherished myth more than an actual description of historical practice.
} 
Furthermore, Spanish treasury officials set out to harmonize the various internal customs duties, tariffs and production quotas, a program intended to modernize and energize the national economy, but which had the effect of enriching the center at the expense of the periphery. The Navarran economy -- and the real humans who worked in it - thus experienced an uneven transition from an older, proto-feudal structure to a modern capitalist economy. Added into the mix, at an already fraught and unstable time, the threat of a French invasion became ever-present after 1789. In 1795, when Mina was just six years old, all men in Pamplona between the ages of 16-60 were notified of their automatic incorporation into active military duty for the Spanish forces to prepare for the war that was surely coming their way. (BARD, 1982: 147) In a very real sense, then, Mina was born and raised in a place that was in transition.

Young Mina's early years were spent in the tiny town of Otano, on the outskirts of Pamplona. He was a popular, energetic boy who loved to scramble over the rocky hillsides and who learned to ride horses well. Mina's extended family was comprised of small-scale farmers and artisans who could reasonably be described in the Navarran context as an aspirational rural middle class. His parents understood the value of education and made sure that their boys learned to read, write and do sums along with their catechisms. Around 1800, when Mina was eleven or twelve, he showed enough interest and intellectual promise that he was sent to Pamplona where he could receive more formal education in the seminary school of an uncle, a priest named Clemente Espoz. While there, he was cared for by aunt Simona Espoz, who was married to Baltazar Saínz, the administrator of the Casa de Misericordia. Young Mina devoured the classics of Spanish literature, was exposed to modern science and mathematics, and experienced both the sensory and social pleasures of living in a town of 14,000 people. (ORTUÑO MARTÍNEZ, 2008: 23-24; RUBIO GOMORA, 2012: 12) He also had to transition from daily use of his first language, Euskara [Basque], to a context where Spanish was spoken. This new reality initiated important shifts in his self-identity and in his understanding of a world that suddenly had become a lot bigger. At that young age, as Mina began the transition from playful childhood to studious youth, he found himself proud to discover that the great chivalric knight Pelayo, one of the great mythic soldierheroes of Spanish literature and history, may have been from Navarra. (BARD, 1982: 20). Right from the start, Mina lived his life in between the Basque and the Spanish, the rural and the urban, the chivalric past and the harsh present.

At some point in mid-1807, Mina moved to Zaragoza to attend the famous 
university there. Zaragoza was a bustling city of 45,000 people, populated by a fertile mix of feisty students, bourgeois merchants, and a significant military garrison. As he had not shown any interest in a religious vocation, Mina enrolled in a humanities course with the intention of becoming a lawyer. (ZÁRATE, 1985: 34) Although most of the registration records from that era were destroyed by occupying French forces, Mina's program would have included the standard courses in canon and civil law, political economy, history, and Latin. He also had a lot of fun. Like students everywhere, Mina gravitated to life on the streets, spending time in the plazas and taverns around the university with his new friends. His giddiness did not last very long. Within six months, news arrived from Pamplona that on 16 February 1808 General D'Armagnac had occupied the city with 2000 French forces and the great crisis had begun. (TONE, 1994: CHAPTER 3)

Mina transitioned very quickly from being a student clown to being a student organizer. In Zaragoza, he participated in public protests against both the French forces and the Spanish Prime Minister Manuel Godoy, the so-called Prince of Peace. With university classes disrupted and feeling the tug of home, Mina returned to an unrecognizable Pamplona. 4,000 French soldiers had overrun the small city of 14,000 people and pushed them out of their own homes. (GUZMÁN, 1955: 2) Events moved rapidly. By the end of May, Spain's Bourbon monarchs had capitulated to Napoleon's demand and abdicated their throne in favour of the Emperor's younger brother Joseph. The transition from a longstanding autocratic monarchy to a foreign-imposed constitutional regime happened in less than two months, provoking a sense of collective trauma and an outburst of patriotic fury. Regional armies quickly coalesced to mount armed resistance, and throughout the peninsula juntas [governing councils] formed to support the war effort and to provide guidance for panicked populations. The rump of centralized national government existed first in a Regency and then eventually in a representative body known as the Cortes of Cádiz.

The Spanish War of Independence - also known as the Peninsular War initiated and accelerated a significant transition in Spanish political culture, namely the tension between civilian political intellectual types and a newly professionalized and legitimized military class with aspirations to leadership. (RICKETTS, 2017: 7) Again, Francisco Xavier Mina operated in a transitional space that straddled both camps. In his early adult years, the exigencies of the moment gave him little leisure time to contemplate politics and theories of governance. His immediate concern was homeland 
defence and so he, like hundreds of thousands of other regular Spanish folk, took up arms and joined the patriotic resistance. He fought under Carlos Aréizaga in the formal armies of Alto Aragón under Joaquín Blake and José de Palafox, participating in the two brutal sieges of Zaragoza and in traditional battles at Alcañiz, Belchite, and many others. These commanders recognized Mina's charisma and organizational talent, and gave him the autonomy to form a mobile, rapid-response guerrilla unit in Navarra. Although not much more than twenty years old, Mina was popular, energetic and consistently able to outwit French commanders by interrupting their communication and supply lines. (ANDRÉS MARTÍN, 2007: 34) He became especially famous for attacks on French couriers which provided Spanish commanders with valuable intelligence and funds. In just one striking example, Mina captured 150 French soldiers on a supply convoy in January 1810. (“PORTUGUESE PAPERS”, 1810) Mina was so successful that Napoleon himself took notice and made it a high strategic priority to capture the young guerrilla. In March of that year, he was seized during a raid on his grandmother's village and hauled off to France in chains.

\section{Prison Years in France, Failed Revolt in Spain}

After six weeks' interrogation in Bayonne, Mina was transferred to a tower cell block at the fortress of Vincennes outside Paris where he was held with other high-value prisoners of state including: Spanish generals José de Palafox, Carlos O’Donnell, Joaquín Blake, and Josef Fernán Núñez de los Ríos; diplomats Pedro de Macañaz, the Conde Fernán Núñez, and Miguel de Lardizábal; guerrilla fighter Antonio Abad; French General François Antoine Desnoyers, the Baron de Kolly, and the conspiratorial Polignac brothers. (ALBOIZE and MAQUET, 1844: 315) During his imprisonment, Mina learned to speak passable French and came into contact with a spectrum of ideas, attitudes and actions emanating from the French Revolution and subsequent Empire of Napoleon. He was a high-value prisoner, suffering in uncomfortable physical conditions for his wartime efforts to defend Navarra (and, by extension, Spain). At the same time, French Army Command recognized Mina's innate talents as a guerrilla leader and on more than one occasion offered him a post in their service. Twice the young man rejected their overtures, once in late 1811 and then again in 1813, when he wrote back 
with a taunting message that he would accept release and would happily go to Italy as they requested but only "to soak in the hot springs at Tivoli", not to fight. (MINA to DESMARETS, 22 March 1811)

Mina spent nearly four years at Vincennes in the paradoxical position of resisting his French captors while learning from his fellow French prisoners. He formed a particularly close friendship with Victor Fanneau de La Horie, a revolutionary general whose opposition to Napoleon's dictatorship landed him in prison. Over a period of more than a year, the unlikely pair met in Vincennes' library and discussed not just military strategy and history, but also Enlightenment philosophy and the original ideals that had inspired the French Revolution. Together they embarked on a course of study that became a substitution for his university classroom. Sharing a common interest in military history and human nature, they read Tacitus, Plutarch, Polybius and Xenophon, while trying to determine what constitutes civic virtue and the nature of heroism. (ORTUÑO MARTÍNEZ, 2008: 64; GUZMÁN, 1955: 155) La Horie was not just a bitter enemy of Napoleon, he was also a relative of young Victor Hugo and shared the emerging Romantic sentiment about the true locus of national value being found in its regular folk, not the artificialities of high society. In this context, Mina's lived experience as a rural Basque guerrilla merged with academic lessons he drew from a sophisticated program of study of the ancients and conversations with a politically engaged Frenchman in his third language. During the time he was held in Vincennes, Mina's care and concern for people close to home slowly transitioned into a more abstract understanding of the threat that the existence of tyranny anywhere posed to people everywhere.

Upon Mina's release from prison on 16 April 1814, he requested a passport for Spain and hurried home to see his family in Navarra. During his four-year absence, things had changed. His uncle Francisco Espoz had become a fearsome regional military leader who had taken to calling himself Francisco Espoz y Mina during the war. Together they travelled to Madrid to press their claims to rewards, pensions and employment in the institutions of the restored monarchy. It was a reasonable expectation; after all, they and others like them had fought valiantly to chase the French usurper from the Spanish throne and assumed that their efforts would be met with gratitude and respect. That was not the case. Instead, Ferdinand VII and his group of revanchist advisors were intent on purging all remaining elements of the liberal constitutional interregnum and its supporters from Spanish society. Espoz y Mina had 
requested the title of Lieutenant General and to be made Viceroy of Navarra, a status that had been granted to José de Palafox in Aragón. (ORTA RUBIO, 1979: 527) Not only did the restored King Ferdinand VII reject this request, he also proclaimed that Espoz y Mina, who had embraced the former constitutional regime, was nothing more than a robber, a tyrant, and an oppressor. Rumors started to float that Mina and other military officers would soon be arrested as traitors and conspirators. (FERDINAND VII, 1824: 238; ESDAILE, 1988: 297)

Shocked at the treatment that he and his uncle received after their great service in Navarra, young Mina wrote to Justo Pérez Pastor, editor of the Madrid newspaper El Procurador General del Rey y de la Nación, in their defense. He lamented that "[a] few days ago, Field Marshal Francisco Espoz arrived at this court, his only goal being to pay his respects to our beloved Sovereign Don Fernando VII, on whose behalf he had fought so many, oh-so-many heroic battles" and instead found himself unwelcome and his accomplishments belittled. A court functionary condescended to recognize that Espoz y Mina had killed and driven out some important French leaders, but said that he had not done anything impressive after the initial victories; instead, the government's position was that the Field Marshal was nothing more than a "tyrant and a thief among the people." (MINA to PÉREZ PASTOR, 9 JULY 1814) ${ }^{3}$ The official's harsh judgement provoked a strong emotional reaction because it represented a personal attack on his family and his professionalism. As Mina said to Pérez Pastor, “General Espoz has enough greatness of soul to look upon such slanderous insults with the highest contempt, content with the testimony of his conscience and the approval of the good people who know how to recognize merit and virtue. But I, who cannot look with indifference upon one who attacks the honor that my uncle has won, without showing himself insensitive to the blood ties that unite me to him, call for all the judges and inhabitants of the Kingdom of Navarra, from Alto Aragón and the Basque Provinces" to raise their voices and reject this insult to their countrymen. They were patriots who had served their nation well and now found themselves tossed aside by the very King who owed his throne to their efforts. In a conciliatory move, Spanish Minister of War Miguel de Lardizábal offered Xavier Mina a command of royalist forces in New Spain, which the young man quickly rejected, saying that he could not take up such a post because he was “an implacable enemy of tyranny." (RAMOS PEDRUEZA, 1937: 22) Ironically,

\footnotetext{
${ }^{3}$ Original in El Procurador General del Rey y de la Nación (23 July 1814).
} 
just three years later Mina would be dead in Mexico fighting against the forces he had once been offered to lead.

Thus shut out of any officially-sanctioned role in the restored Spanish regime, Francisco Espoz y Mina and his nephew launched a conspiratorial uprising set for Pamplona on the night of September $25^{\text {th }}$. On that date, the members of the garrison were supposed to rise up, take control of the town, and restore the liberal Cádiz Constitution which Ferdinand had cancelled. The revolt was poorly planned and it was not entirely clear that the rank-and-file shared these sentiments, so it failed by midmorning, sending Espoz y Mina, Mina, and all their associates scrambling for safety across the French border to escape the reach of Spanish loyalists. The event had a greater historical significance, however. It was the first pronunciamiento [military declaration of the right to rule] in Spanish history and thus another step along the path toward legitimizing military intervention in politics. (COMELLAS, 1958: 104-106; MINA APAT, 1981: 74) As one Spanish historian argues, the Spanish army had been the institution least affected by Ferdinand's ruthless purge of liberals from public life, so its members saw themselves as the protectors of the Cádiz tradition and "as an instrument of struggle." (ARTOLA, 1990: 45) It was a model that relied heavily on spontaneous insurrection that was based on structural discontent and galvanized by a charismatic personality at its helm. (CASTELLS, 1989: 21) It was clearly also a transitional sort of vision that sat uncomfortably between singular heroes of past chivalric actions and the more longer-term modern imperative of building support and legitimacy from the bottom up. In historian Brian Hamnett's assessment, the Mina and Porlier pronunciamientos are significant because they clearly proved that "the personal stand of one man was insufficient to provoke a national rising." (HAMNETT, 1984: 225; RICKETTS, 2017: 173) Nevertheless, many ill-starred folk did continue to try to initiate spontaneous uprisings against oppressive regimes, including Mina himself.

\section{Recruitment in England and the United States}

Finding himself in France again, this time as an exile with a price on his head, Mina accepted some clandestine assistance and sneaked across the English Channel where he joined the sizable contingent of Spanish emigres who had gathered there. He 
spent almost a year in England where he started to describe Ferdinand and the Spanish government as "atrocious". (MINA to CASTLEREAGH, 1 June 1815) His circle included important members of the liberal Spanish exile community, prominent Whig politicians and various other reformers, including: José María Blanco White, Álvaro Florez Estrada, Antoni Puigblanc, the Conde de Toreno, Lord Holland, Jeremy Bentham, James Perry, William Walton, and the editors of the Edinburgh Review. (ORTUÑO MARTÍNEZ, 2001: 468) In this context, Mina's education entered its third phase. To his Spanish military experience, and his French prison studies, Mina the student now added an exposure to English technocratic liberalism and a belief in free trade as a motor of progress. He formed a close friendship with J. D. R. Gordon, a member of a prominent merchant family with strong trading and finance interests in Mexico, when shared a residence in the same hotel for an extended period. (JIMÉNEZ CODINACH, 1991: 334n) After 1815, Mina started to include references to trade, commerce and - eventually - economic equality as part of his understanding of the sort of world that a transnational liberal movement might be trying to create. Having secured financial support from Lord Holland, the Gordons' firm, and other shadowy quarters, Mina recruited approximately 30 soldiers, bought a ship called the Caledonia, and made a plan to serve the Spanish cause by helping to emancipate its most lucrative overseas territory, Mexico.

Mina and his small group quietly left Liverpool on 15 May 1816 and hove into Chesapeake Bay in June, but the news of their expedition had flown ahead of them thanks to a network of Spanish spies. ${ }^{4}$ The Caledonian's captain deceptively registered his boat's contents as commercial goods with the port manager in Baltimore, although everyone (including Spanish Envoy and Minister Plenipotentiary Luis de Onís) knew who they really were. For the next year, Mina had dozens of meetings with American investors, military recruits, and outfitters up and down the eastern seaboard. He received the greatest support from groups in New York, Baltimore and New Orleans, all of whom had the reasonable expectation that the emancipation of the Spanish colonies would lead not just to the fraternal spread of liberty but also the opening of lucrative trade markets. It was a difficult period for him, however, because Mina's command of English was not strong, and he began to realize how enormously difficult his planned

\footnotetext{
${ }^{4}$ The extensive correspondence between Spanish Ambassador to the Court of St. James, the Conde de Fernán Núñez, and British Foreign Secretary Lord Castlereagh about Mina's activities can be found at Spain, Archivo General de Simancas, Estado, Legajo 8.177.
} 
enterprise would be. As he wrote to Lord Holland, "[m]y efforts here have not had a happy result" but, he assured his friend, preparations to dislodge the enemy would continue nonetheless. (MINA to HOLLAND, 19 September 1815)

While in the United States, Mina also began to compose the first of a series of justificatory proclamations that he would issue over the course of the next year through which transitions in his thought and ideology can be traced. He had begun his fighting life as a teenaged guerrilla leader but by 1816 his strategic perception of the battlefield had expanded to include the press and public opinion. Under the influence of his friend Fray Servando Teresa de Mier, a fiercely iconoclastic and polemical Mexican priesthistorian who had signed on as the Vicar-General of the expedition, Mina's liberalism became more consciously developed and radical. Mier had been in European exile since 1796 and had developed a transatlantic reputation as the author of several biting antiimperial arguments, including a polemic with José María Blanco White in the pages of El Español (1811-1812), and Historia de la Revolución en Nueva España, antiguamente Anáhuac (1813). Mier relished a good fight and his righteous anger on behalf of fellow Mexicans helped to push Mina's understanding of empire further into the radical camp.

Mina spent more than a year going up and down the eastern coast of the United States, including a brief sojourn to the Caribbean where he spent two weeks on Haiti meeting with Simón Bolívar and the agents of President Alexandre Pétion. (LEWIS, 1969: 458-60) Bolívar had received a letter from Mina written to him from Baltimore and had formed a high opinion of the young Spanish adventurer. Bolívar told his friend Maxwell Hyslop that Mina was a remarkable leader who "has organized things in a creditable way." (BOLÍVAR to HYSLOP, 4 OCTOBER 1816) Although each revolutionist invited the other to join his expedition, in the end, they remained committed to separate theaters of war, but their activities continued to draw from the same pool of external financial resources, personnel, corsair support and communication lines. Most significantly, Mina secured the allegiance of French corsair Luis Aury who was in the process of a severe break with Bolívar and the Cartagena émigrés over a power struggle with Luis Brión. Mina, Aury, and U.S. Colonel Henry Perry established their own military base on Galveston Island and began training for their invasion of Mexico. As Mina became more familiar with the American context, his understanding of the liberal fight against tyranny shed some of its national boundaries and transitioned into something that was more universal. Mina's ragtag band of recruits was truly transnational, transcultural and multi-lingual. He had his long-time Navarran 
friends with him, as well as people from France, Prussia, Sweden, the United States, Canada, England, Scotland, Ireland, Catalonia, Naples, Poland, the Danish Caribbean islands, bayou pirates from Barataria, black sailors from Haiti, and several Mexicans.

As the men loaded up the ships in Galveston Bay, Mina said farewell to his friend Mariano Montilla who had opted to join Simón Bolívar's expeditionary forces seeking to liberate his birthplace in Venezuela. As these friends saw it, they were fighting the same fight. Mina wrote: "I hope that when you arrive at your patria [fatherland] that you can join in its emancipation. In ours, I not only do I count on your friendship, but that of all caraqueños [people from Caracas] with whom I have been united by my ideas ever since I embraced the American cause." (MINA to MONTILLA, 1 APRIL 1817) And then the two men sailed off to meet their separate destinies.

\section{Expedition to Mexico}

After a few days of sailing on mostly calm waters, the expedition touched briefly on the Mexican shoreline at the mouth of the Rio Bravo River to take on fresh water and supplies and to scout information about the location and size of royalist outposts. Mina offered a short speech intended to affirm for his troops that they were embarking on a venture that was both sacred and assured of success. He addressed them without reference to national origin as "Companions in arms", an indication that their shared homeland was not a place but an idea. (MINA, 12 APRIL 1817) The proclamation is just one paragraph long - a half-page in print form - but in it he managed to invoke several of the key concepts of early nineteenth century Spanish liberal republicanism. He reiterated that they were there "to work for the liberty and independence of Mexico", alongside the Mexicans themselves who had begun their struggle seven years earlier. Mina assured them that "hombres de bien [men of rank and quality] will recognize and appreciate your virtue, and you shall receive your reward, namely honor in triumph. You know that by stepping on Mexican soil, we come not to conquer but to aid the illustrious defenders of the most sacred rights of man in society."

A few days later, around April 21, Mina and his expedition disembarked and set up a small base of operations at Soto la Marina, a tiny outlet along the coast of the Mexican state today known as Tamaulipas. Upon landing, the expedition began to 
transition from being a plan to being a reality. Mina was now the commander of a real force entering a real theater of war. While most of the men remained there to unload arms and supplies, Mina ventured inland a few miles to meet the local townsfolk and assure them that they were coming as liberators. In fact, one of his first concerns was to neutralize potential hostility. To that end, on April 22, the expedition's young American printer Samuel Bangs dashed off one of Mina's first orders, a short decree issued under the authority of "the new government" which stated that Mexican enlistees were welcome and would be clothed and fed and paid regularly. The volunteers could choose a time-limited period of service or sign up for the duration of the conflict. Mexican property would be respected, and the guaranteed but Spanish property was subject to confiscation and distribution to patriots. And finally, residents were free to sell their products, including tobacco, without any licence required. (MINA, 22 APRIL 1817) Clearly Mina had received good advance intelligence about the nature of local complaints against the Spanish government's fiscal policies which had drained their homeland of so much silver, coins and natural resources. It was also a new sort of document, one with a republican aesthetic - short, direct, unadorned, and based on a world view that assumed a politically aware populace that associated their well-being with that of the patria not the monarchy.

Not all of Mina's printed works were so practical. On April 25, he issued two important canonical documents: the "Soto la Marina Proclamation to Spaniards and Americans" which was a highly personal biographical statement that identified his past and present loyalties, and also the more formal "Bulletin \#1 of the First Mexican Auxiliary Army." Both documents have parts that draw heavily from his earlier productions like the Galveston proclamation, although they are sharper and have strengthened the lines of argument most likely to appeal to Mexicans. Mina's printer was a young American named Samuel Bangs and his editor-in-chief was a Cuban named Joaquín Infante who had been driven from the island for his part in a Masonic plot in 1812. (FERNÁNDEZ PRIETO, 2015: 560) As part of that movement, Infante had drafted the first constitution written on Cuban soil and his presence on the expedition reinforced Mina's adherence to the principles of liberal, representational democracy growing out of the Cádiz experiment. Infante's influence probably pushed Mina further toward the radical end of the liberal spectrum. Infante's idealized society, as represented in his draft constitution, explicitly condoned religious pluralism, making space for people of other faiths to participate in public life. (SANTOVENIA, 1959: 25- 
28).

Mina directed his Soto la Marina proclamation to Spaniards and Americans, clearly identifying the existence of two distinct groups. (MINA, 25 APRIL 1817) As he introduced himself to a new continent, Mina said that "as I separate myself from the political association for whose prosperity I have worked since my tender youth and bind myself to another which is dissenting from it so that I might aid them, I think it my duty to explain my motives and what has led me to take this resolution." As a student at Zaragoza, and the fighting against the French invader, Mina says he felt a sacred fire in himself, fighting alongside others in the name of destroying the enemy. Over time, he realized that real freedom meant not just ousting Napoleon's troops, but also breaking the chains of illiberality and servitude that had crept into governance over the centuries. As he had come to realize "after we had re-established the dignity of man and our ancient laws on our soil, we had thought Fernando VII, who had been our companion and also a victim of oppression" would have restored the rightful benefits to the Spanish people whose sacrifice had won the war. But he gave nothing, in fact, he became a tyrant himself. And so, Mina decided: "We owe him nothing." Feeling frustrated as Spain's King conquered his own people, Mina suddenly understood that "it is only the King, the employees and the monopolists who approve of the subjection of America to the detriment of Americas." Spaniards, he said, "are quite aware that there is no Spain without America." As he sees it, in an emancipated America, there will be no exclusive privileges, nor sale of government favors and jobs; because American ports will open to foreign trade, and this business will pass into the hands of a more numerous and enlightened class; because a liberated America undoubtedly will revive Spanish industry which until now has been sacrificed to the interests of a few men."

Mina experienced a surprisingly neutral welcome from the locals at Soto la Marina. He stressed that he and his men had arrived with a new democratic vision that would allow them to choose their own leaders from among the most talented, no longer would they have to suffer at the whims of those who could afford to buy themselves an office. By May, Mina had become so heady with his success that he wrote to the Spanish Commander-General of the Provincias Internas, an unpopular man named Joaquín de Arredondo, asking him to switch sides and unite himself with the expeditionary forces who were on the right side of history. Mina made a similar offer to the regional commander Lieutenant Felipe de la Garza in which he invited him to become "one of the liberators." (MINA to GARZA, 27 APRIL 1817) More 
significantly, Mina counselled Garza "to take a look around you at this fertile soil and observe the poverty of its inhabitants - you must realize that it is all due to the governmental system." Mina said he had enough equipment for a thousand strong men, and that he was sure that he and the valiant Mexicans who had already joined him would succeed in what he described as their "great struggle." It is a small point, but a significant one. Where nearly all contemporary writers and orators spoke of "our great cause," Mina had begun to frame it as "our great struggle." His letter to Garza indicates that he was no longer animated by a patriotic rejection of a foreign presence alone, but rather that he now recognized that the problems were not just political, they were economic and systemic.

The Mina expedition enjoyed some dramatic early successes. In the span of just ten days in mid-June 1817, Mina's vastly outnumbered forces scored big victories over Spanish troops at Valle del Maíz (June 8), at Peotillos (June 15) and the at Real de Pinos (June 18). ${ }^{5}$ Mexican Viceroy Juan Ruiz de Apodaca was enraged by Arredondo's failure to interdict and eliminate the threat. In July, he tried to cut off popular support for Mina's band by offering a broad pardon to anyone who would desert, which included money, property, and, in the case of foreigners, free passage back to the United States border. (APODACA, 12 JULY 1817) By August, Mina's fortunes had shifted. Arredondo's forces had arrived from the northern garrisons and joined with those of Pascual de Liñán in the Bajío to tip the balance of power against Mina. He suffered a devastating loss at the siege of the Fuerte de Remedios and found he could not rely on the word of his fellow Mexican insurgent leader José Antonio Torres who thought Mina had usurped his rightful place as leader. Mina sent increasingly desperate message to the insurgent government at Jaujilla, pleading with them to send reinforcements because, as he said, "these guys are no good for attacking [fortified] walls." (MINA TO MINISTER OF WAR, 17 SEPTEMBER 1817)

In a proclamation to his men in mid-October, Mina clearly felt the momentum slipping away from him. He addresses European Spaniards - and those of his native province of Navarre specifically - telling them to think of America as their only home now. Retreat and return is no longer a possibility. (MINA, 19 OCTOBER 1817) His mind returned to the core of his youthful identity, calling upon "[n]oble Navarrans, my

\footnotetext{
${ }^{5}$ The marches, battles and physical environment are described in detail by the participant James Brush in "Journal of the Expedition and Military Operations of General Don Fr. X. Mina in Mexico, 1816-1817," Huntington Library, mssHM 472.
} 
generous countrymen, valiant Spaniards all! My sentiments remain the same, that when I had earned your confidence, we would struggle together on behalf of our beloved Spain and the sacred rights of mankind." His personal resentment toward King Ferdinand and the House of Bourbon had only grown as it melded with the rural Mexicans' complaints and transitioned into a realization that the whole system was rotten. As he said "[o]ur American brothers have suffered the greatest vexations as a result of Spain's pressing needs. The considerable sums that their provinces voluntarily contributed to the war against Napoleon and the universal cry with which they proclaimed [their loyalty to] the King are being repaid with the devastation of their lands, the blood shed by their sons." Mina, the Navarran boy who had grown up with stories of Spanish chivalry now considered his homeland to be "tyrannized and destroyed." There would be no going back. He counseled his men to "[ $\mathrm{t}]$ hink of America as the home of your own birth. This just decision will save men's blood and will assure your lives and interests. It will give you the rights of Citizenship. You will be done with the evils of war. [...] I protest in your name, which forms an entire republican body." Less than a month later, Mina was dead, executed by a firing squad to the general acclaim of royalists on both sides of the Atlantic.

Francisco Xavier Mina was a transitional man in an Age of Transitions. He lived his short life moving along a spectrum of places, ideas and transformations that reflected those of the broader world around him. He was born in Navarra and died in America, a geographic trajectory that foreshadowed the fulcrum of power shifting from Europe to the Americas over the nineteenth century. Mina fought for the absent Spanish King Fernando VII during the Peninsular War, but he very quickly felt personally oppressed by the restored monarchy and so went to Mexico to help topple the same Crown he had originally wanted to save. As Mina came to realize, monarchs were just men - and often not good men - and thus had to be constrained by laws and constitutions. He had read many books, conversed with many people from many places, and seen crushing poverty up close. Over time and through direct experience, Mina's political consciousness not only became awakened, but it moved further and further into the realm of the radical. Shortly before his death, he had not only declared himself to be a republican, he had also started to call for fundamental changes to the social and economic structures that had underpinned the empire. Francisco Xavier Mina was caught between the old world and the new, and his actions on the battlefields of Spain and America reflected the many transitions going on around him: from rural to urban 
space, from monarchies to republics, from feudal economies to capitalist ones, and from Europe to America. Mina may have been executed as a traitor to monarchical Spain in 1817, but he was exhumed and lauded as a hero to republican Mexico in 1823 alongside Miguel Hidalgo, José María Morelos and others founding fathers. It was his final transition.

\section{Bibliographic references}

ALBOIZE, M. M. and Maquet, A. (1844). Le donjon de Vincennes, depuis sa fondation jusqu'a nos jours. Paris: Administration de Librairie.

ANDRÉS MARTÍN, Juan Ramón. (2007). Mina y dos independencias: ¿héroe o traidor? Pregón: Revista Navarra de Cultura. vol. 30. pp. 34-37.

APODACA, Juan Ruiz de. (12 July 1817). Indulto contra Mina. Spain. Archivo General de Indias, Estado 31, N.64.

ARTOLA, Miguel. (1990). La burguesía revolucionaria, 1808-1874. Madrid: Alianza Editorial.

BARD, Rachel. (1992). Navarra: The Durable Kingdom. Lincoln: University of Nebraska Press.

BOLÍVAR, Simón Bolívar to HYSLOP, Maxwell Hyslop. (4 October 1816) em BOLÍVAR, Simón. (1976). Obras Completas. Mexico City: Editorial Cumbre. vol. 3. pp. 221-222.

BURGO, Jaime del. (1992). Historia de Navarra. Madrid: Editorial Rialp.

CASTELLS, Irene. (1989). La utopía insurreccional del liberalismo. Barcelona, Editorial Crítica.

COMELLAS, José Luis. (1958). Los primeros pronunciamientos en España, 18141820. Madrid: Consejo Superior de Investigaciones Científicas, Escuela de Historia Moderna.

ESDAILE, Charles. (1988). War and Politics in Spain, 1808-1814. The Historical Journal. vol. 31, no. 2. pp. 295-317. Junho.

FERDINAND VII. (1824). Memoirs of Ferdinand VII, King of the Spains. Transl. Michael J. Quin. London: Hurst, Robinson, \& Co.

FERNÁNDEZ PRIETO, Leida. (2015). Una mirada sobre las independencias americanas: el diario político de Joaquín Infante, de lo local a lo continental. Revista de Indias. vol.75. no. 264. pp. 550-570.

GUZMÁN, Martín Luis. (1955). Javier Mina: héroe de España y de México. México: Compañía General de Ediciones.

HAMNETT, Brian. (1984). Liberal Politics and Spanish Freemasonry, 1814-1820. History. vol. 69. no. 226. pp. 222-237.

JIMÉNEZ CODINACH, Guadalupe. (1991). La Gran Bretaña y la independencia de México 1808-1821. Mexico: Fondo de la Cultura Económica.

LEWIS, William F. (1969). Simón Bolívar and Xavier Mina: A Rendezvous in Haiti. Journal of Inter-American Studies. vol. 11. no. 3. pp. 458-465. Julho. 
MINA, Xavier to Monsieur DESMARETS, Jefe de la $1^{\text {st }}$ División de la Policía General en Paris (22 March 1813). Reimpresso em GUZMÁN, Javier Mina, 169-170.

MINA, Francisco Xavier Mina to PÉREZ PASTOR, Justo. (9 July 1814). Reimpresso em ORTUÑO MARTÍNEZ, Manuel. (2011). El verano de 1814 en Madrid y Pamplona. Huarte de San Juan. vol. 18. pp. 385-413.

MINA, Xavier to CASTLEREAGH, Robert Stewart, Lord. (1 June 1815). Great Britain. National Archives. Foreign Office. 72/182, ff. 56-57.

MINA, Xavier to HOLLAND, Henry Vassall Fox, Lord. (19 September 1816). British Library. Add MS 51626, f.173.

Mina, Xavier to MONTILLA, Mariano Montilla. (1 April 1817). Reimpresso em MIRAMÓN, Alberto. (1997). Biografía de Sardá, y Cronicón del Nuevo Reyno. Bogotá: Imprenta Nacional de Colombia.

MINA, Francisco Xavier Mina. (12 April 1817). Proclamation to the enlisted soldiers of his expedition. Stirling Library. Yale University. Latin American MSS 307, box 11, f. 181.

MINA, Xavier. (22 April 1817). Decreto. Mexico. Archivo General de la Nación. Historia 152, ff. 98-98v.

MINA, Francisco Xavier. (25 April 1817). Proclama de Soto la Marina. A los Españoles y Americanos. Reimpresso em HERNÁNDEZ Y DÁVALOS, Juan. (1985). Colección de documentos para la historia de la guerra de independencia de México. Mexico: Instituto Nacional de Estudios Históricos. Vol. 6. pp. 862-865. Documento \#984.

MINA, Xavier to GARZA, Felipe de la. (27 April 1817). Mexico. Archivo General de la Nación. Historia 152, legajo 1, ff. 71v-72.

MINA, Xavier to Señor MINISTER OF WAR. (17 September 1817). University of Texas at Austin, Benson Library. Hernández y Dávalos Collection HD 10-5.5831.

MINA, Javier (19 OCTOBER 1817). Proclamation to the Noble Navarrans, My Generous Countrymen. University of Texas at Austin, Benson Library. Hernández y Dávalos Collection, HD 10-5.855.

MINA APAT, María Cruz. (1981). Fueros y revolución liberal en Navarra. Madrid: Alianza Editorial.

ORTA RUBIO, Esteban. (1979). Javier Mina, 'El Mozo'. Príncipe de Viana. vol. 40, n. 156-157. pp. 507-540.

ORTUÑO MARTÍNEZ, Manuel. (2008). Vida de Mina: guerrillero, liberal, insurgente. Madrid: Trama Editorial.

ORTUÑO MARTÍNEZ, Manuel Ortuño. (2001). Xavier Mina, en la revolución liberal insurgente en México (bases para una hipótesis de trabajo). Em GIL NOVALES, Alberto, ed. La revolución liberal. Congreso sobre la Revolución liberal española en su diversidad peninsular (e insular) y americana. Madrid: Editorial Del Orto.

"PORTUGUESE PAPERS." (14 September 1810). The Times. no. 8088.

RAMOS PEDRUEZA, Rafael. (1937). Francisco Javier Mina. Combatiente clasista en Europa y América. México: Editorial México Nuevo.

RICKETTS, Mónica. (2017). Who Should Rule? Men of Arms, the Republic of Letters, and the Fall of the Spanish Army. New York: Oxford University Press.

RUBIO GOMORA, Juan Guillermo. (2012). Anclas hacia la libertad: Xavier Mina y Fray Servando Teresa de Mier. Guadalajara: Groppe Libros.

SANTOVENIA, Emeterio. (1959). Estudio preliminar em INFANTE, Joaquín. Proyecto de Constitución para la Isla de Cuba. Caracas: Academia Nacional de la Historia.

TONE, John Lawrence. (1994). The Fatal Knot: The Guerrilla War in Navarre and the Defeat of Napoleon in Spain. Chapel Hill: University of North Carolina Press. 
ZÁRATE, Verónica. (1985). Xavier Mina. México: Instituto Nacional de Estudios Históricos de la Revolución Mexicana.

Artigo recebido em 20 de abril de 2020.

Aprovado em 11 de junho de 2020

DOI: $10.12957 /$ intellectus.2020.52471 